\title{
Natural Radioactivity Levels of Soil Samples from Nile Islands in EL-Mynia Governorate, Egypt
}

\author{
M. A. M. Uosif ${ }^{1 *}$, A. M. A. Mostafa ${ }^{1}$, Reda Elsaman ${ }^{1}$ and Elsayed Moustafa ${ }^{1}$ \\ ${ }^{1}$ Faculty of Science, Al-Azhar University, Assuit branch, Egypt \\ *Dr_Mohamed_Amin@Lycos.com (MAMUo) \\ Fax: +20882148095
}

\begin{abstract}
The activity concentrations of ${ }^{226} \mathrm{Ra},{ }^{232} \mathrm{Th}$ and ${ }^{40} \mathrm{~K}$ in twenty - one soil samples collected from five Nile Islands in EL-Mynia governorate have been measured by gamma ray spectroscopy. These islands are used for tourist and agricultural activities. The average activity concentrations of ${ }^{226} \mathrm{Ra},{ }^{232} \mathrm{Th}$ and ${ }^{40} \mathrm{~K}$ ranged from $14 \pm 0.8$ to $21 \pm 1$, $10 \pm 0.5$ to $23.3 \pm 1$ and $356.5 \pm 18$ to $411 \pm 20.5 \mathrm{BqKg} g^{-1}$ respectively. The radiological hazards [radium equivalent $\left(R a_{e q}\right)$, dose rate, annual effective dose (AED), external hazard $\left(H_{e x}\right)$ internal hazard $\left(H_{i n}\right)$, gamma radiation hazard index $\left(I_{\gamma r}\right)$ and excess lifetime cancer risk (ELCR)] for tourists and farmers were calculated. The data were discussed and compared with those given in the literatures.
\end{abstract}

Keywords: Nile Islands, Soil, Tourism, Agriculture and Radiological hazards

\section{Introduction}

In Egypt, Nile islands are characterized as the most fertile lands and others are characterized by their unique topographic position due blending of sand dunes mountains on both Nile banks with the greenery of the islands in the presence of vegetation and animal diversity which is rarely to be present in other environments, also some of which are considered resting stations for migratory birds [1]. In Egypt the Nile islands can be divided according to use: residential islands-tourist islands- agricultural islands- and neglected islands [2].

The Nile islands formed as a result of the less competence of the river to move the bed load, so it has collected to form the early stage of the island after that it received more deposits to extend in length and width [3].There are a lot of natural radioactive nuclides which contains ${ }^{226} \mathrm{Ra},{ }^{232} \mathrm{Th}$ and ${ }^{40} \mathrm{~K}$, in the environment (soil, plant, sediment, water and air), also there is from man-made sources such as those from nuclear sources [4]. Rocks and soil contribute significantly to the internal and external exposure to environmental radioactivity by gamma rays and beta radiation that increase the risk to human health [5]. In addition, the exposure by inhalation has a variety of health effects such as chronic lung disease, and lack of sharp white blood cells, anemia, and necrosis of the mouth [6].

The aim of present study was focused on determining the activity concentrations of ${ }^{226} \mathrm{Ra},{ }^{232} \mathrm{Th}$ and ${ }^{40} \mathrm{~K}$ for soil from Nile Islands in EL-Mynia governorate, Upper Egypt and calculation of the radiological hazards to these islands for farmers and tourists.

*Corresponding author 


\section{Materials and Methods}

\subsection{Study Area}

Nile Islands (IN) irrigated from Nile River and divided into five Islands coded by (IN1 to IN5). These islands are used for tourism and agriculture and located in the following places Figure (1):

- The Nile Island coded by (IN1) is located in Deirmawas city, near the village of Ammaria Sharkea, this island is used for agriculture.

- $\quad$ The Nile Island (IN2) is located in Abu-Qurqas city, near the village of Bani Hassan El Shorouk (Archaeological area), these island are used for tourism and agriculture.

- $\quad$ The Nile island (IN3) is located in Samalott city, near the village of Jabal al-Tair, where there is (the Church of the Virgin Mary), this island is used for tourism.

- The Nile Island (IN4) is located in Mattay city, near the village of EL-Shekh Hassan, this island is used for agriculture.

- The Nile Island (IN5), located in in Bne-Mazar city, near EL-Shekh Fatl village, this island is used for agriculture.

\subsection{Sample Description}

Using X-ray fluorescence technique (XRF), the major range values of elemental concentrations of the studied soils samples were: $\mathrm{MgO}(1.6874-1.8980 \%), \mathrm{Al}_{2} \mathrm{O}_{3}$ (10.4458 - 11.1474\%), $\mathrm{SiO}_{2}(53.1568-54.0308 \%), \mathrm{K}_{2} \mathrm{O}(1.8636-1.9053 \%), \mathrm{CaCo}_{3}$ $(8.8089-9.3013 \%), \mathrm{TiO}_{2}(3.4709-3.6609 \%), \mathrm{MnO}(0.5629-0.6174 \%)$ and $\mathrm{Fe}_{2} \mathrm{O}_{3}$ $(18.3864-19.0563 \%)$. Also the chemico-physical characteristics of soil under study such as hydrogen Ion $(\mathrm{pH})$, quantity of organic matter (O.M) and texture of soil were performed using ( $\mathrm{pH}$ meter, Walkley - Black method and Particle size distribution by Pipette method) respectively. The average value of $(\mathrm{pH})$ was $(7.41)$ and (O.M) was $(1.43 \%)$, also texture of soil was (Sandy Clay Loam).

\subsection{Sample Collection and Preparation}

The collected soil samples form Nile islands each are about $500 \mathrm{gm}$ in weight. All samples were dried in an oven at about $110 \mathrm{C}^{\circ}$ for $24 \mathrm{~h}$ to ensure that moisture is completely removed. All samples were crushed, homogenized, and sieved through a 200 $\mu \mathrm{m}$, which is the optimum size enriched in heavy minerals. Samples were placed in polyethylene beaker, of $250 \mathrm{~cm}^{3}$ volume each and weighted. The beakers were completely sealed for 4 weeks to reach secular equilibrium radium and thorium, and their progenies [7].

\subsection{Instrumentation and Calibration}

Radioactivity measurements were performed by gamma ray spectrometer, employing a scintillation detector $3 \times 3$ inch. Its hermetically sealed assembly which includes a highresolution $\mathrm{NaI}(\mathrm{Tl})$ crystal, photomultiplier tube, an internal magnetic/light shield, aluminum housing and a 14 pin connector coupled to PC-MCA Canberra Accuspes. In order to determine the background distribution in the environment around the detector, an empty sealed beaker was counted in the same manner and in the same geometry as the samples [8]. The measurement time of activity or background was 43,200 s. The offline analysis of each measured g-ray spectrum has been carried out by a dedicated software program genie 2000 [9]. 


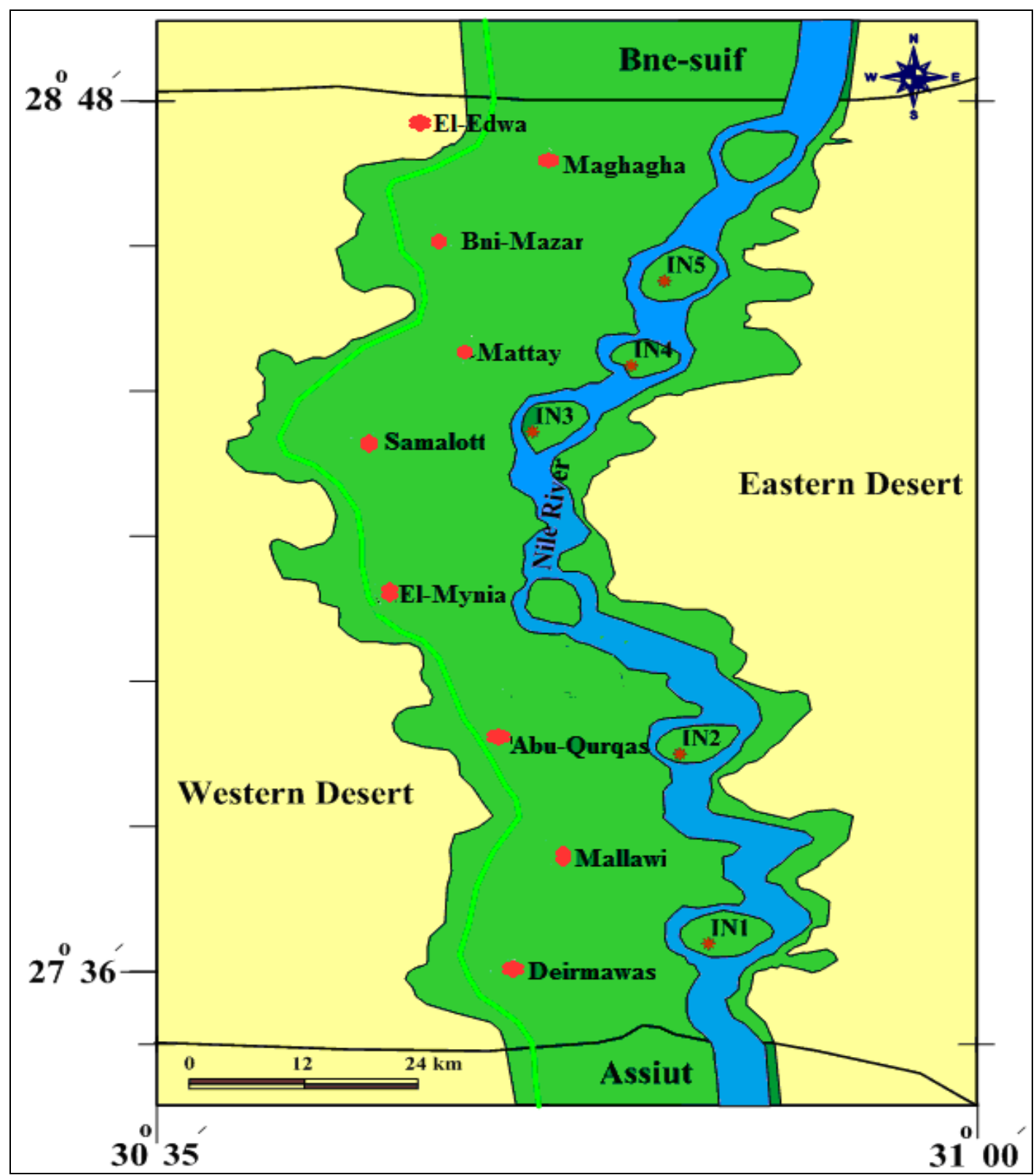

Figure 1. Location Map of the Studied Nile Islands Samples in El-Mynia, Governorate, Upper Egypt

\subsection{Analytical Method}

\subsubsection{Activity Estimation}

The activity concentration in $\mathrm{Bq} \mathrm{kg}^{-1}$ (A) was obtained as follows [7].

$$
A=\frac{N_{\mathrm{p}}}{e \times \eta \times m}
$$

Where $N_{p}$ is the count per second of sample (cps), e is the abundance of the $\gamma$-peak in radionuclide, $\eta$ is the measured efficiency for each gamma line observed for the same number of channels either for the sample, and $\mathrm{m}$ is sample mass in kilograms. 


\subsubsection{Radiological Hazards Indices}

In order to compare the activity concentration of samples, which contain ${ }^{226} \mathrm{Ra},{ }^{232} \mathrm{Th}$ and ${ }^{40} \mathrm{~K}$, the radium equivalent activity as a common index was used to obtain the sum of activities. Therefore, the $\mathrm{Ra}_{\mathrm{eq}}$ is given by [10]:

$$
\mathrm{Ra}_{\mathrm{eq}}=\mathrm{C}_{\mathrm{Ra}}+1.43 \mathrm{C}_{\mathrm{Th}}+0.077 \mathrm{C}_{\mathrm{k}}
$$

Where $\mathrm{C}_{\mathrm{Ra}}, \mathrm{C}_{\mathrm{Th}}$ and $\mathrm{C}_{\mathrm{K}}$ are the activities of ${ }^{226} \mathrm{Ra},{ }^{232} \mathrm{Th}$ and ${ }^{40} \mathrm{~K}\left(\mathrm{Bqkg}^{-1}\right)$ respectively.

The absorbed dose rates due to gamma radiations in air at $1 \mathrm{~m}$ above the ground surface for the uniform distribution of the naturally occurring radionuclides $\left({ }^{226} \mathrm{Ra},{ }^{232} \mathrm{Th}\right.$ and ${ }^{40} \mathrm{~K}$ ) were calculated based on guidelines provided by [11]. The conversion factors used to compute absorbed gamma dose rate (D) in air per unit activity concentration in $\mathrm{BqKg}^{-1}$ (dry weight) corresponds to $0.462 \mathrm{nGyh}^{-1}$ for ${ }^{226} \mathrm{Ra}, 0.604 \mathrm{nGyh}^{-1}$ for ${ }^{232} \mathrm{Th}$ and $0.042 \mathrm{nGyh}^{-1}$ for ${ }^{40} \mathrm{~K}$. Therefore $\mathrm{D}$ can calculate as follows [12]: Where $\mathrm{C}_{\mathrm{Ra}}, \mathrm{C}_{\mathrm{Th}}$ and $\mathrm{C}_{\mathrm{K}}$ having the same meaning as in Eq. (2).

$$
\mathrm{D}=0.462 \mathrm{C}_{\mathrm{Ra}}+0.604 \mathrm{C}_{\mathrm{Th}}+0.0417 \mathrm{C}_{\mathrm{K}}
$$

The external hazard index $\left(\mathrm{H}_{\mathrm{ex}}\right)$ was determined from the criterion formula as follow [13]: Where $C_{R a}, C_{T h}$ and $C_{K}$ having the same meaning as in Eq. (2).

$$
H_{e x}=\frac{C_{R a}}{370}+\frac{C_{T h}}{259}+\frac{C_{K}}{4180} \leq 1
$$

On the other hand, the internal hazard index $\left(\mathrm{H}_{\text {in }}\right)$ gives the internal exposure to carcinogenic radon and its short-lived progeny [14], and it is given by the following formula [10]:

$$
\mathrm{H}_{\mathrm{in}}=\left(\mathrm{C}_{\mathrm{Ra}} / 185+\mathrm{C}_{\mathrm{Th}} / 259+\mathrm{C}_{\mathrm{K}} / 4810\right) \leq 1
$$

Where $\mathrm{C}_{\mathrm{Ra}}, \mathrm{C}_{\mathrm{Th}}$ and $\mathrm{C}_{\mathrm{K}}$ having the same meaning as in Eq. (2).

Another radiation hazard index, the representative level index, $\mathrm{r} \gamma$, used to estimate the level of gamma-radiation hazard associated with the natural radionuclides in the investigated samples, is defined from the following formula [15], Where $C_{R a}, C_{T h}$ and $C_{K}$ having the same meaning as in Eq. (2).

$$
\mathrm{I}_{\gamma \mathrm{r}}=0.0067 \mathrm{C}_{\mathrm{Ra}}+0.01 \mathrm{C}_{\mathrm{Th}}+0.00067 \mathrm{C}_{\mathrm{K}}
$$

The annual effective dose is determined using the following equations [16]:

$$
\operatorname{AED}\left(\mu \mathrm{Sv} \mathrm{y}^{-1}\right)=\mathrm{D}\left(\mathrm{nGy} \mathrm{h}^{-1}\right) \times 8760 \mathrm{~h} \times 0.7 \mathrm{~Sv} \mathrm{~Gy}^{-1} \times 0.2 \times 10^{-3}
$$

Excess Lifetime Cancer Risk (ELCR) can be defined as the excess probability of developing cancer at a lifetime due to exposure level of human to radiation. Excess Lifetime Cancer Risk (ELCR) was calculated by using the following equation [12]:

\section{$\mathrm{ELCR}=\mathrm{EDR} \times \mathrm{DL} \times \mathrm{RF}$}

Where EDR is the annual effective dose equivalent, DL is duration of life (30-70 year) and $\mathrm{RF}$ is risk factor $\left(\mathrm{Sv}^{-1}\right)$ fatal cancer risk per Sievert. For stochastic effects, ICRP 60 uses values of $(\mathrm{RF}=0.05)$ for public. The worldwide recommended value of $0.29 \times 10^{-3}$ [11].

\section{Results and Discussion}

\subsection{Activity Concentrations}

A summary of measurements for the activity concentration $\left(\mathrm{Bqkg}^{-1}\right)$ of the natural radioactivity due to ${ }^{226} \mathrm{Ra},{ }^{232} \mathrm{Th}$ and ${ }^{40} \mathrm{~K}$ of twenty one agricultural soil sample collected from five Nile island's coded by (IN1: IN5) are given in table (1). It can be concluded 
that the activity concentrations values of ${ }^{226} \mathrm{Ra}$ ranged from $9 \pm 0.5$ to $25 \pm 1 \mathrm{Bqkg}^{-1}$. The corresponding values are from $5 \pm 0.2$ to $27 \pm 0.6$ and from $259 \pm 13$ to $450 \pm 22 \mathrm{Bqkg}^{-1}$ for ${ }^{232} \mathrm{Th}$ and ${ }^{40} \mathrm{~K}$, respectively. The ${ }^{40} \mathrm{~K}$ average concentrations in all Nile Island's samples are higher than ${ }^{226} \mathrm{Ra}$ and ${ }^{232} \mathrm{Th}$ concentrations, which may be due to the geological description of the investigated area, where the Nile island's soil is sandy clay loam and it contains high percentage of calcium carbonate and high potassium level [17].

\section{Table 1. Activity Concentrations $\left(\mathrm{BqKg}^{-1}\right)$ of ${ }^{226} \mathrm{Ra},{ }^{232} \mathrm{Th}$ and ${ }^{40} \mathrm{~K}$ in Soil Samples Collected from (IN)}

\begin{tabular}{|c|c|c|c|c|c|c|c|}
\hline \multirow{2}{*}{$\begin{array}{c}\text { Location } \\
\text { code }\end{array}$} & \multirow{2}{*}{$\begin{array}{c}\text { Sample } \\
\text { code }\end{array}$} & \multicolumn{6}{|c|}{ Activity $\left(\mathrm{BqKg}^{-1}\right)$} \\
\hline & & \multicolumn{2}{|c|}{${ }^{226} \mathbf{R a}$} & \multicolumn{2}{|c|}{${ }^{232} \mathbf{T h}$} & \multicolumn{2}{|c|}{${ }^{40} \mathrm{~K}$} \\
\hline \multirow{4}{*}{ IN1 } & S1 & 13 & \pm 0.7 & 8 & \pm 0.3 & 367 & \pm 18.4 \\
\hline & S2 & 18 & \pm 0.9 & 14 & \pm 0.7 & 327 & \pm 16.3 \\
\hline & S3 & 15 & \pm 0.8 & 10 & \pm 0.4 & 348 & \pm 17.4 \\
\hline & S4 & 19 & \pm 1 & 12 & \pm 0.5 & 384 & \pm 19.2 \\
\hline \multicolumn{2}{|c|}{ Mean } & 16.3 & \pm 0.9 & 11 & \pm 0.5 & 356.5 & \pm 18 \\
\hline \multirow{4}{*}{ IN2 } & S5 & 16 & \pm 0.8 & 14 & \pm 0.7 & 365 & \pm 18.4 \\
\hline & S6 & 16 & \pm 0.9 & 15 & \pm 0.8 & 373 & \pm 18.6 \\
\hline & S7 & 15 & \pm 0.7 & 5 & \pm 0.2 & 352 & \pm 17.6 \\
\hline & S8 & 12 & \pm 0.3 & 6 & \pm 0.3 & 364 & \pm 18.3 \\
\hline \multicolumn{2}{|c|}{ Mean } & 14.8 & \pm 0.7 & 10 & \pm 0.5 & 363.5 & \pm 19 \\
\hline \multirow{4}{*}{ IN3 } & S9 & 14 & \pm 0.7 & 27 & \pm 1.4 & 369 & \pm 21.9 \\
\hline & S10 & 9 & \pm 0.5 & 8 & \pm 0.4 & 363 & \pm 18.1 \\
\hline & S11 & 19 & \pm 1 & 13 & \pm 0.7 & 347 & \pm 20.4 \\
\hline & S12 & 14 & \pm 0.7 & 6 & \pm 0.3 & 355 & \pm 17.5 \\
\hline \multicolumn{2}{|c|}{ Mean } & 14 & \pm 0.8 & 13.5 & \pm 0.7 & 358.5 & \pm 19.5 \\
\hline \multirow{5}{*}{ IN4 } & S13 & 21 & \pm 1.1 & 14 & \pm 0.7 & 397 & \pm 19.9 \\
\hline & S14 & 14 & \pm 0.7 & 7 & \pm 0.4 & 406 & \pm 20.3 \\
\hline & S15 & 15 & \pm 0.8 & 11 & \pm 0.5 & 420 & \pm 21 \\
\hline & S16 & 24 & \pm 1.2 & 10 & \pm 0.5 & 430 & \pm 21.5 \\
\hline & S17 & 12 & \pm 0.7 & 16 & \pm 0.9 & 403 & \pm 20 \\
\hline \multicolumn{2}{|c|}{ Mean } & 17 & \pm 0.9 & 11.6 & \pm 0.6 & 411 & \pm 20.5 \\
\hline \multirow{4}{*}{ IN5 } & S18 & 25 & \pm 1.2 & 25 & \pm 1.3 & 371 & \pm 18.6 \\
\hline & S19 & 19 & \pm 1 & 21 & \pm 1.1 & 450 & \pm 22.5 \\
\hline & S20 & 17 & \pm 0.9 & 23 & \pm 1.2 & 443 & \pm 22.2 \\
\hline & S21 & 23 & \pm 1.1 & 24 & \pm 1.2 & 259 & \pm 12.9 \\
\hline \multicolumn{2}{|c|}{ Mean } & 21 & \pm 1 & 23.3 & \pm 1 & 380.8 & \pm 19 \\
\hline
\end{tabular}

The mean concentrations of ${ }^{226} \mathrm{Ra}$ and ${ }^{232} \mathrm{Th}$ for Nile Island's samples were lower than the permissible activity levels which are 35 and $35 \mathrm{Bqkg}^{-1}$, respectively [11]. In the other side, the mean concentrations of ${ }^{40} \mathrm{~K}$ were lower than the permissible activity levels (370 $\mathrm{Bqkg}^{-1}$ ) except for samples from IN4 and IN5, this may be due to Urea improved (UI) and proprioceptive urea (PU) which used as popular fertilizers in this islands . Figure (2), shows a comparison between the average activity concentrations in $\mathrm{Bqkg}^{-1}$ for soil samples collected from Nile islands.

The good correlation $\left(R^{2}=0.70\right)$ between average activity concentrations of ${ }^{226} \mathrm{Ra}$ and ${ }^{232} \mathrm{Th}$ as shown in figure (3). The correlation indicates that, the ${ }^{226} \mathrm{Ra}$ and ${ }^{232} \mathrm{Th}$ are representative of a common geological origin [18], also there are a poor correlation 
between ${ }^{40} \mathrm{~K}$ and ${ }^{226} \mathrm{Ra}\left(\mathrm{R}^{2}=0.015\right)$, and between ${ }^{40} \mathrm{~K}$ and ${ }^{232} \mathrm{Th}\left(\mathrm{R}^{2}=0.019\right)$, see in Figure (4 and 5).

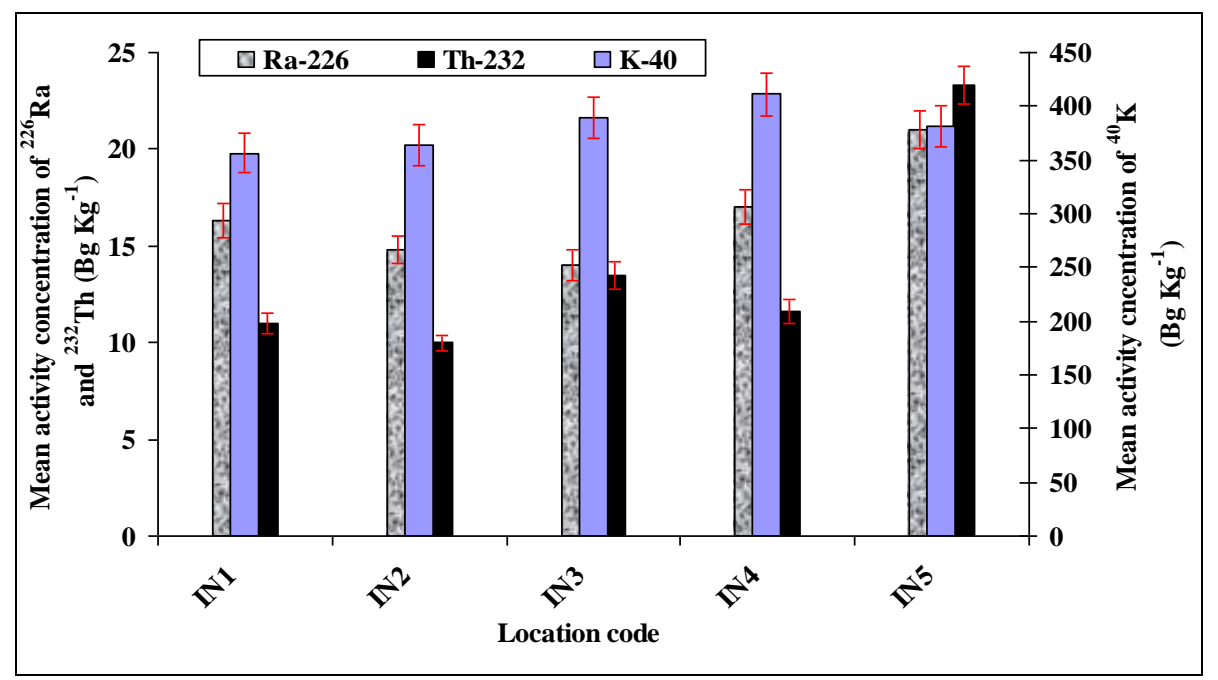

Figure 2. Comparison between Average Values of ${ }^{226} \mathrm{Ra},{ }^{232} \mathrm{Th}$ and ${ }^{40} \mathrm{~K}$ Activity Concentration in $\mathrm{Bqkg}^{-1}$ for Soil Samples from (IN)

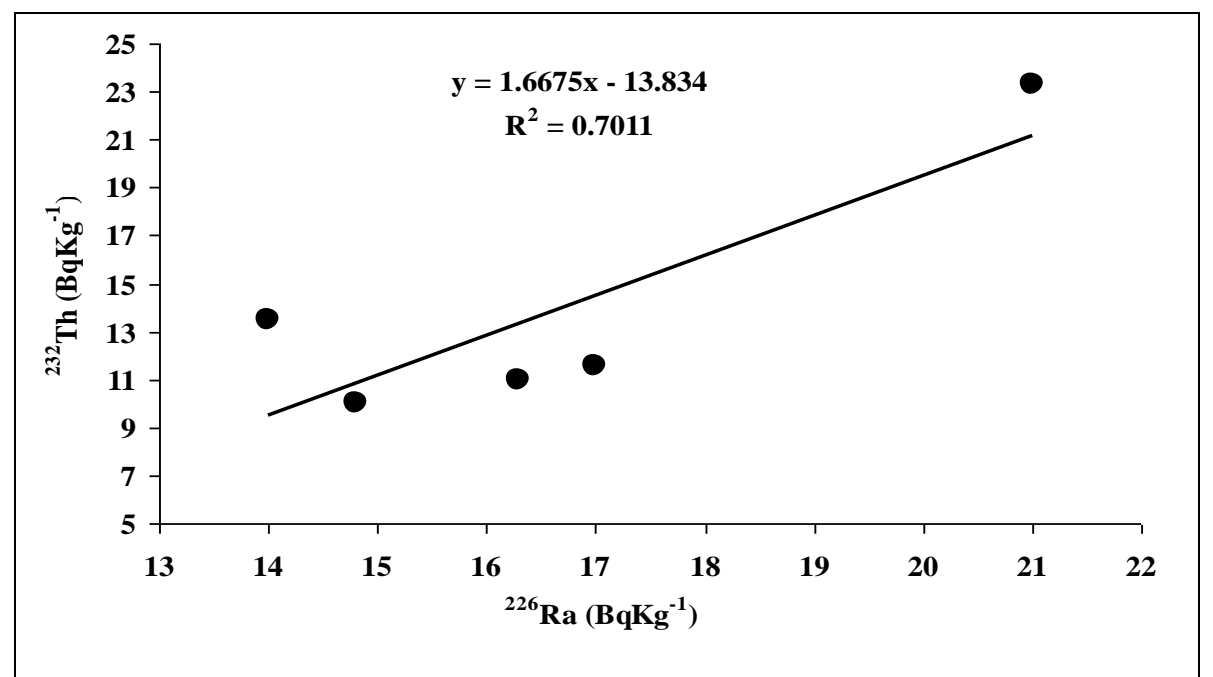

Figure 3. The Correlation between Activity Concentrations of ${ }^{226} \mathrm{Ra}$ and ${ }^{232} \mathrm{Th}$ in Soil Samples from (IN) 


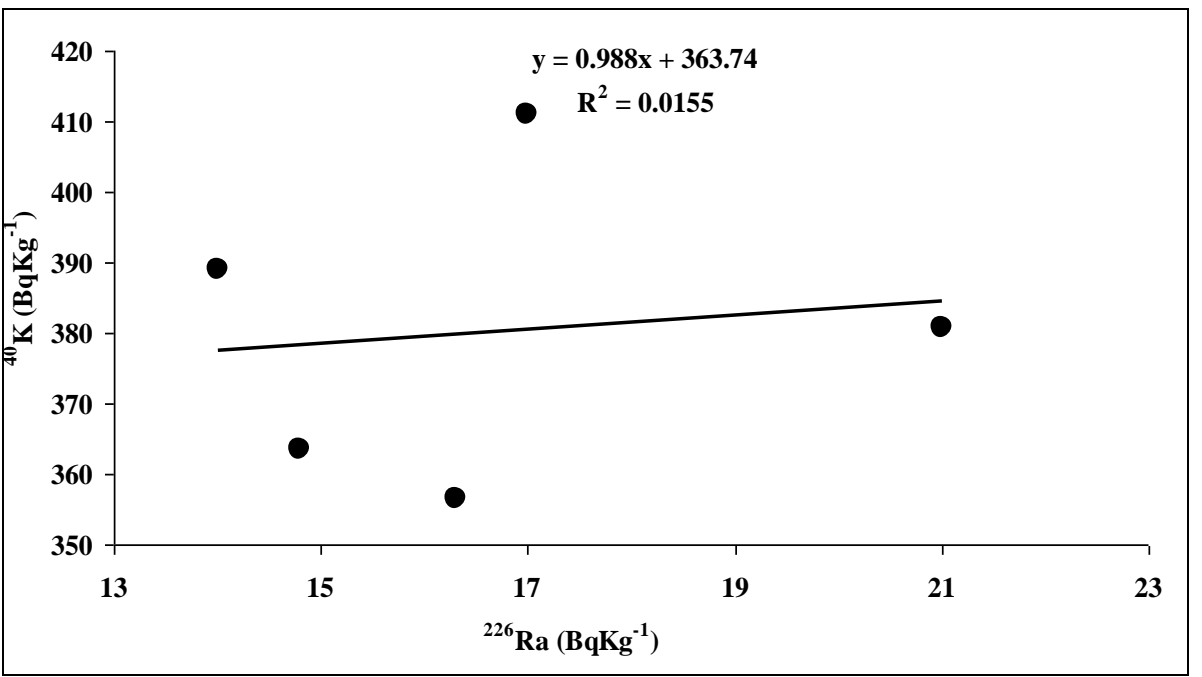

Figure 4. The Correlation between Activity Concentrations of and ${ }^{226} \mathrm{Ra}{ }^{40} \mathrm{~K}$ in Soil Samples from (IN)

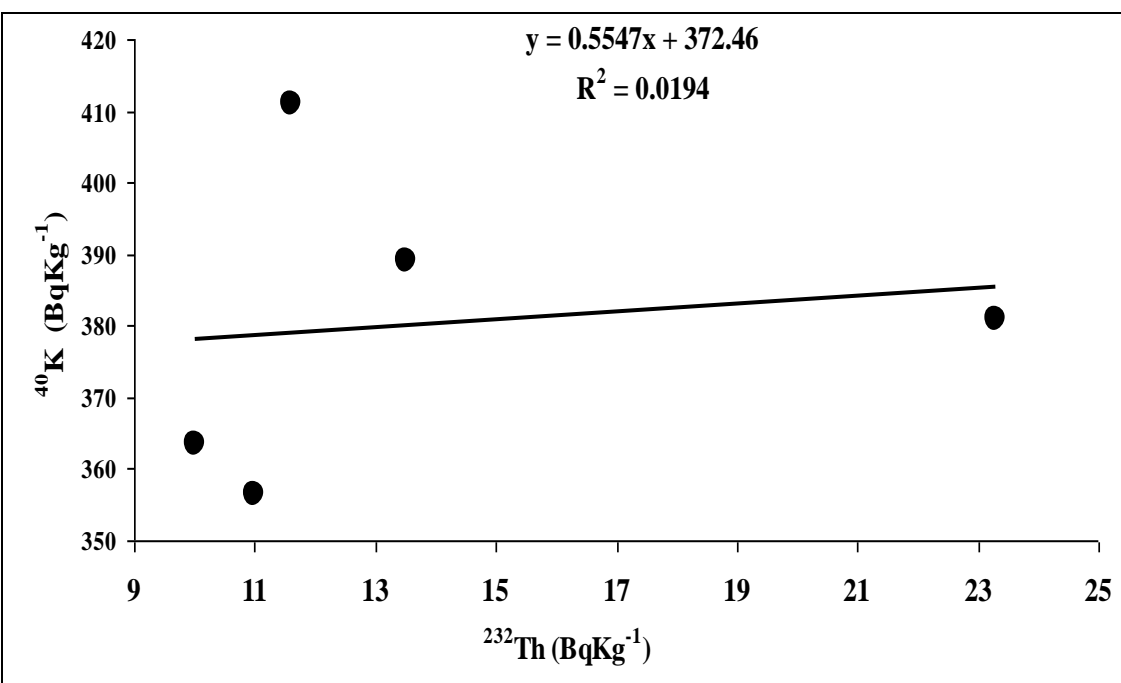

Figure 5. The Correlation between Activity Concentrations of ${ }^{40} \mathrm{~K}$ and ${ }^{232} \mathrm{Th}$ in Soil Samples from (IN)

3.1.1. Comparison of Activity Concentrations with Similar Studies in other Countries:

The activity concentrations of ${ }^{226} \mathrm{Ra},{ }^{232} \mathrm{Th}$ and ${ }^{40} \mathrm{~K}$ in soil samples from the studied islands were compared with those from similar investigations in other countries and presented in table (2). As can be seen from Table (2), the mean values of ${ }^{226} \mathrm{Ra}^{, 232} \mathrm{Th}$ and ${ }^{40} \mathrm{~K}$ in soil were in the range or less than the corresponding values in the listed countries. 
Table 2. Comparison of the Activity Concentrations of the Soil with other Countries

\begin{tabular}{cccccc}
\hline \multirow{2}{*}{ Country } & Samples & \multicolumn{3}{c}{ Activity $\left(\mathbf{B q K g}^{\mathbf{- 1}}\right)$} & \multirow{2}{*}{ Ref. } \\
\cline { 3 - 5 } & & ${ }^{\mathbf{2 2 6}} \mathbf{R a}$ & ${ }^{232} \mathbf{T h}$ & ${ }^{40} \mathbf{K}$ & \\
\hline Egypt (EL-Mynia) & Nile Island's Soil & $\mathbf{1 6 . 7}$ & $\mathbf{1 3 . 8}$ & $\mathbf{3 8 2}$ & Present work \\
Egypt (Qena) & Nile Island's Soil & 11.9 & 10.5 & 1636 & {$[17]$} \\
Egypt (Aswan) & Agricultural Soil & 16.92 & 21.96 & 505.92 & {$[19]$} \\
$\begin{array}{c}\text { Egypt (Abou Zabal } \\
\text { region) }\end{array}$ & Cultivated Soil & 31.12 & 10.96 & 264.1 & {$[20]$} \\
$\begin{array}{c}\text { Egypt (Alexandria) } \\
\text { Pakistan(Pakka }\end{array}$ & Agricultural Soil & 16.43 & 18.31 & 268.16 & {$[21]$} \\
Anna) & Fertilized Soil & $30-38$ & $50-64$ & $560-$ & {$[22]$} \\
World wide & Soil & 35 & 35 & 400 & {$[11]$} \\
\hline
\end{tabular}

\subsection{Radiological Hazards}

The values of radium equivalent $\mathrm{Ra}_{\mathrm{eq}}\left(\mathrm{Bqkg}^{-1}\right)$ for soil samples collected from (IN) were listed in Table (3). The lowest average value of $\mathrm{Ra}_{\mathrm{eq}}$ is $56.9 \mathrm{Bqkg}^{-1}$ in soil samples collected from the location coded by $\mathbf{I N 3}$, while the highest average of $\mathrm{Ra}_{\mathrm{eq}}$ is $83.7 \mathrm{Bqkg}^{-1}$ in soil samples IN5. These values are less than the maximum admissible value of 370 $\mathrm{Bqkg}^{-1}$ [11]. ${ }^{232} \mathrm{Th}$ is the main contributor to $\mathrm{Ra}_{\mathrm{eq}}$ in samples from IN5, while ${ }^{40} \mathrm{~K}$ is main contributor to $\mathrm{Ra}_{\mathrm{eq}}$ in other samples as shown in Figure (6). These indicate that the contribution to Raeq is owing to ${ }^{40} \mathrm{~K}$ followed by ${ }^{232} \mathrm{Th}$ followed by ${ }^{226} \mathrm{Ra}$.

The calculation of absorbed dose rates (D) for soil samples collected from (IN) are presented in table (3). As shown in table (3), the values of absorbed dose rates due to ${ }^{226} \mathrm{Ra},{ }^{232} \mathrm{Th}$ and ${ }^{40} \mathrm{~K}$, ranged from 24.3 to $41.8 \mathrm{nGyh}^{-1}$. These values are lower than the international limit $59 \mathrm{nGyh}^{-1}$ [11].

Table (3), column 5 shows that the calculated of external hazard values for soil samples collected from (IN) are lower than the unity (permissible level) [11], which do not cause any harm to the tourists, populations and farmers in these locations under investigation. The relative contributions owing to ${ }^{226} \mathrm{Ra},{ }^{232} \mathrm{Th}$ and ${ }^{40} \mathrm{~K}$ were ranged between $(22 \%$ to $27 \%),(25 \%$ to $39 \%)$ and (35\% to $49 \%)$ respectively, these indicate that the contribution to $\left(\mathrm{H}_{\mathrm{ex}}\right)$ is owing to ${ }^{40} \mathrm{~K}$ followed by ${ }^{232} \mathrm{Th}$ followed by ${ }^{226} \mathrm{Ra}$ as shown in Figure (7).

The internal hazard index was calculated for soil samples, those collected from (IN), are listed in table (3). From table (3) the calculated of internal hazard index values for all samples are lower than the unity (permissible level) [11]. The contributions to $\mathrm{H}_{\text {in }}$ owing to ${ }^{226} \mathrm{Ra}$ higher than the contributions to $\mathrm{H}_{\text {in }}$ owing to ${ }^{232} \mathrm{Th}$ and ${ }^{40} \mathrm{~K}$, except for samples from the location coded by (IN3) as shown in Figure (8).

$\gamma$ radiation hazard index $\left(\mathrm{I}_{\gamma}\right)$ was estimated for soil samples under test and the derived values are presented in Table (3). It can be seen that, the values of gamma activity index were ranged from 0.38 to 0.66 . It is observed that, all samples have gamma index $\mathrm{I}_{\gamma}<2$ which indicates gamma dose contribution from these soil samples was not exceed 0.3 $\mathrm{mSv} . \mathrm{y}^{-1}[23]$. The relative contribution to gamma index $\mathrm{I}_{\gamma}$ from ${ }^{40} \mathrm{~K}$ is the highest one, as shown in Figure (9).

Table (3), shows the annual effective doses (AED) from measured soil samples. It can see that AED varied from 29.8 to $51.2 \mu \mathrm{Svy}^{-1} \mu \mathrm{Svy}^{-1}$. These values are less than the world 
average $70 \mu \mathrm{Svy}^{-1}$, reported in [11]. Figure (10) indicate that the contributions to dose rate (D) and annual effective doses (AED) owing to ${ }^{40} \mathrm{~K}$ higher than the contributions owing to ${ }^{232} \mathrm{Th}$ and ${ }^{226} \mathrm{Ra}$.

Finally column 9 of Table (3) gives the results for excess lifetime cancer risk (ELCR) for samples, the highest average value is $1.70 \mathrm{E}-04$ for samples from location coded by IN5, while the lowest average value is 1.21E-04 for samples from IN1 and IN3. These values are lower than the worldwide recommended value of $0.29 \times 10^{-3}$ [11].

Table 3. The Equivalent Radium ( $\left(\mathrm{a}_{\mathrm{eq}}\right)$, Dose Rate(D), Annual Effective Dose (AED), External Hazard $\left(H_{\mathrm{ex}}\right)$ Internal Hazard $\left(\mathrm{H}_{\mathrm{in}}\right)$, y Radiation Hazard index $\left(I_{\mathrm{Y}}\right)$, Excess Lifetime Cancer Risk (ELCR) and Annual Gonadal Dose Equivalent (AGDE) for Soil Collected from (IN)

\begin{tabular}{|c|c|c|c|c|c|c|c|c|}
\hline \multirow[t]{2}{*}{$\begin{array}{c}\text { Location } \\
\text { code }\end{array}$} & \multirow[t]{2}{*}{$\begin{array}{l}\text { Sample } \\
\text { Code }\end{array}$} & $\mathbf{R a}_{\text {eq }}$ & D & $\mathrm{H}_{\text {ex }}$ & $\mathbf{H}_{\text {in }}$ & $\mathbf{I} \gamma$ & AED & ELCR \\
\hline & & $\left(\mathrm{BqKg}^{-1}\right)$ & $\left(\mathrm{nGyh}^{-1}\right)$ & & \multicolumn{4}{|c|}{$\left(\mu \mathrm{Svy}^{-1}\right)$} \\
\hline \multirow{4}{*}{ IN1 } & S1 & 52.3 & 26.2 & 0.14 & 0.18 & 0.41 & 32.1 & $1.12 \mathrm{E}-04$ \\
\hline & $\mathrm{S} 2$ & 62.6 & 30.1 & 0.17 & 0.22 & 0.47 & 36.9 & $1.29 \mathrm{E}-04$ \\
\hline & S3 & 51.1 & 25.6 & 0.14 & 0.18 & 0.40 & 31.4 & $1.10 \mathrm{E}-04$ \\
\hline & S4 & 62.5 & 30.8 & 0.17 & 0.22 & 0.48 & 37.8 & $1.32 \mathrm{E}-04$ \\
\hline \multicolumn{2}{|c|}{ Mean } & 57 & 28 & 0.16 & 0.20 & 0.44 & 34.5 & 1.21E-04 \\
\hline & S5 & 86.5 & 41.0 & 0.23 & 0.27 & 0.66 & 50.2 & $1.76 \mathrm{E}-04$ \\
\hline \multirow[t]{3}{*}{ IN2 } & S6 & 69.5 & 33.9 & 0.19 & 0.24 & 0.53 & 41.6 & $1.46 \mathrm{E}-04$ \\
\hline & S7 & 49.2 & 24.7 & 0.13 & 0.17 & 0.38 & 30.3 & $1.06 \mathrm{E}-04$ \\
\hline & S8 & 48.4 & 24.3 & 0.13 & 0.16 & 0.38 & 29.9 & $1.04 \mathrm{E}-04$ \\
\hline \multicolumn{2}{|c|}{ Mean } & 63.4 & 31 & 0.17 & 0.21 & 0.49 & 38 & 1.33E-04 \\
\hline & S9 & 64.2 & 31.1 & 0.17 & 0.22 & 0.49 & 38.2 & $1.34 \mathrm{E}-04$ \\
\hline \multirow[t]{3}{*}{ IN3 } & S10 & 67.0 & 32.4 & 0.18 & 0.23 & 0.51 & 39.7 & $1.39 \mathrm{E}-04$ \\
\hline & S11 & 48.4 & 24.5 & 0.13 & 0.17 & 0.38 & 30.0 & $1.05 \mathrm{E}-04$ \\
\hline & S12 & 48.0 & 24.3 & 0.13 & 0.16 & 0.38 & 29.8 & $1.04 \mathrm{E}-04$ \\
\hline \multicolumn{2}{|c|}{ Mean } & 56.9 & 28 & 0.15 & 0.19 & 0.44 & 34.5 & 1.21E-04 \\
\hline \multirow{5}{*}{ IN4 } & S13 & 71.2 & 34.6 & 0.19 & 0.25 & 0.54 & 42.4 & 1.49E-04 \\
\hline & S14 & 59.6 & 29.6 & 0.16 & 0.20 & 0.46 & 36.3 & $1.27 \mathrm{E}-04$ \\
\hline & S15 & 62.9 & 31.2 & 0.17 & 0.21 & 0.49 & 38.3 & 1.34E-04 \\
\hline & S16 & 67.3 & 33.5 & 0.18 & 0.25 & 0.52 & 41.1 & 1.44E-04 \\
\hline & S17 & 63.2 & 33.3 & 0.18 & 0.21 & 0.50 & 39.2 & $1.36 \mathrm{E}-04$ \\
\hline \multicolumn{2}{|c|}{ Mean } & 64.9 & 32.5 & 0.18 & 0.22 & 0.50 & 39.5 & 1.38E-04 \\
\hline & S18 & 89.1 & 41.8 & 0.24 & 0.31 & 0.66 & 51.2 & 1.79E-04 \\
\hline \multirow[t]{3}{*}{ IN5 } & S19 & 84.2 & 40.4 & 0.23 & 0.28 & 0.64 & 49.6 & $1.74 \mathrm{E}-04$ \\
\hline & S20 & 84.4 & 40.3 & 0.23 & 0.27 & 0.64 & 49.5 & $1.73 \mathrm{E}-04$ \\
\hline & S21 & 76.9 & 35.4 & 0.21 & 0.27 & 0.56 & 43.4 & $1.52 \mathrm{E}-04$ \\
\hline \multicolumn{2}{|c|}{ Mean } & 83.7 & 39.5 & 0.23 & 0.28 & 0.63 & 48.5 & 1.70E-04 \\
\hline
\end{tabular}




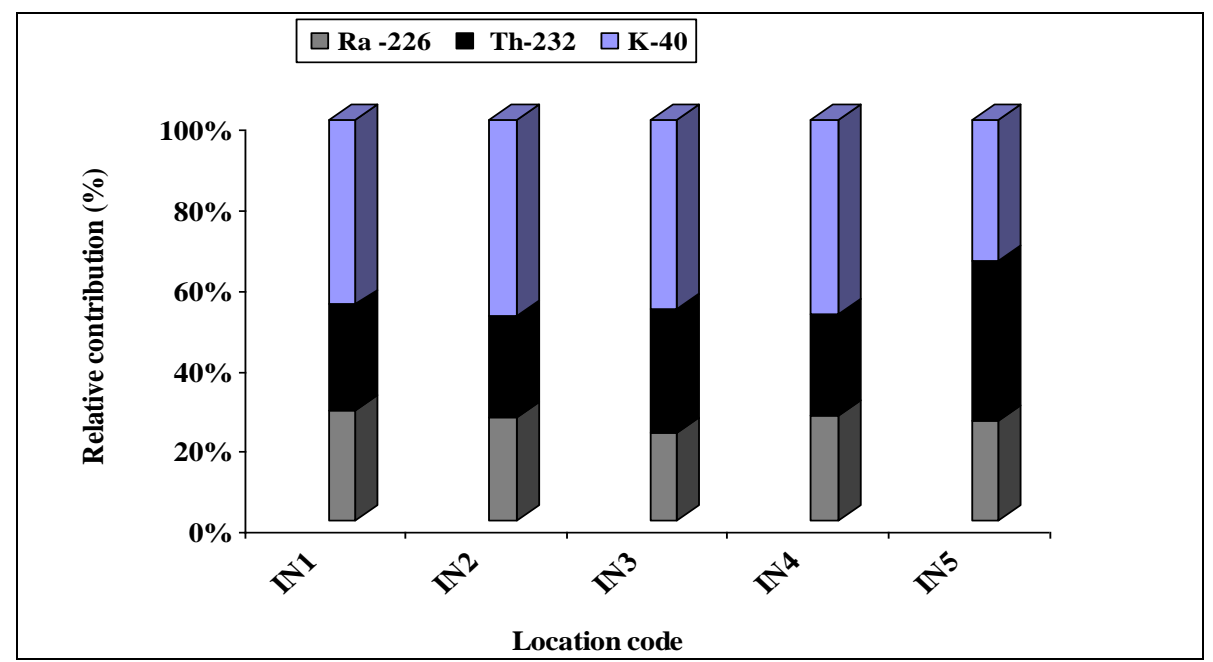

Figure 6. The Relative Contribution (\%) of ${ }^{226} \mathrm{Ra},{ }^{232} \mathrm{Th}$ and ${ }^{40} \mathrm{~K}$ to $\mathrm{Ra}_{\mathrm{eq}}$ in Soil Samples from (IN)

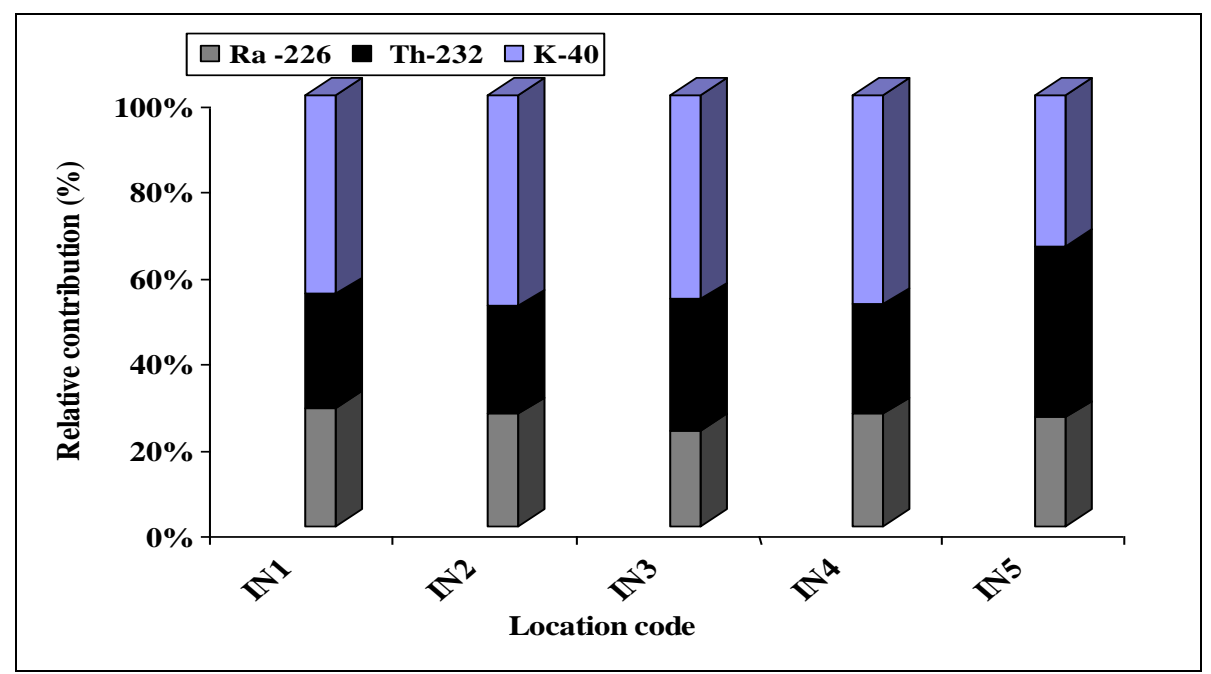

Figure (7). The Relative Contribution (\%) of ${ }^{226} \mathrm{Ra},{ }^{232} \mathrm{Th}$ and ${ }^{40} \mathrm{~K}$ to $\mathrm{H}_{\mathrm{ex}}$ in Soil Samples from (IN)

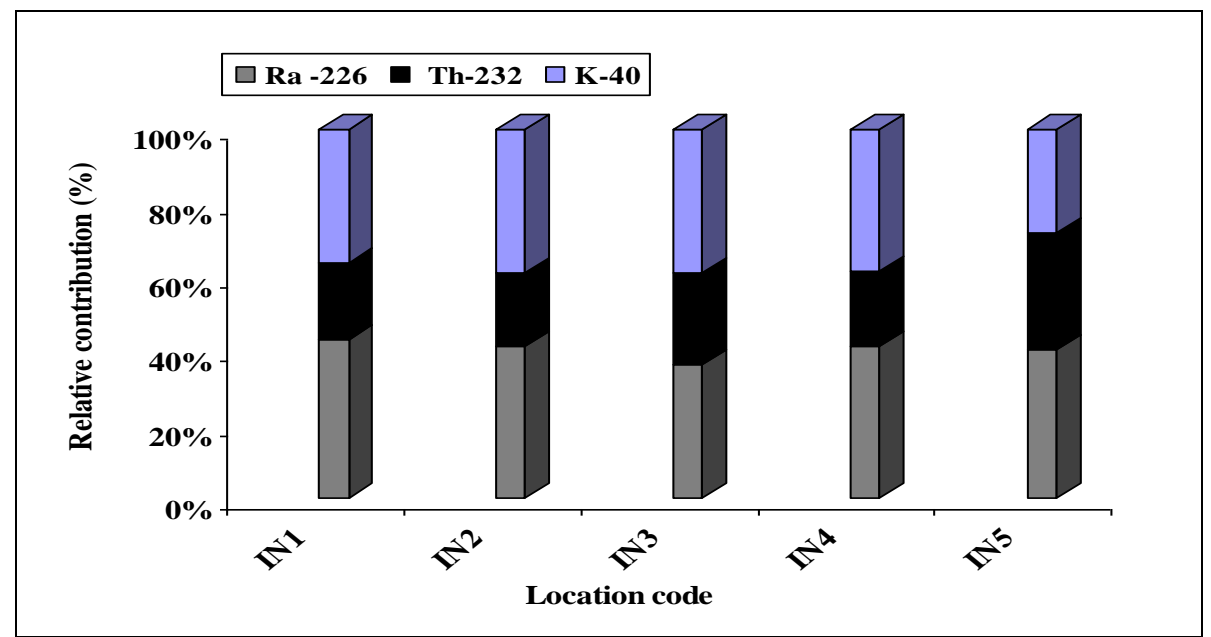

Figure 8. The Relative Contribution (\%) of ${ }^{226} \mathrm{Ra},{ }^{232} \mathrm{Th}$ and ${ }^{40} \mathrm{~K}$ to $\mathrm{H}_{\text {in }}$ in Soil Samples from (IN) 


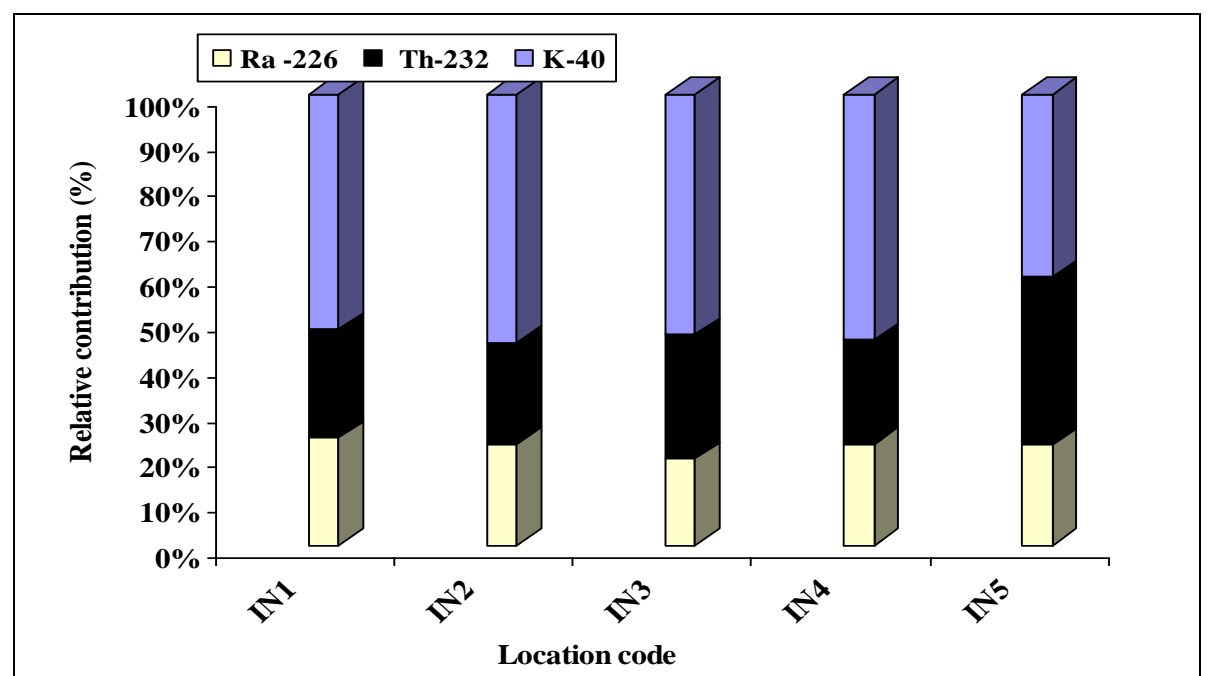

Figure 9. The Relative Contribution (\%) of ${ }^{226} \mathrm{Ra},{ }^{232} \mathrm{Th}$ and ${ }^{40} \mathrm{~K}$ to $\mathrm{I}_{\mathrm{Y}}$ in Soil Samples from (IN)

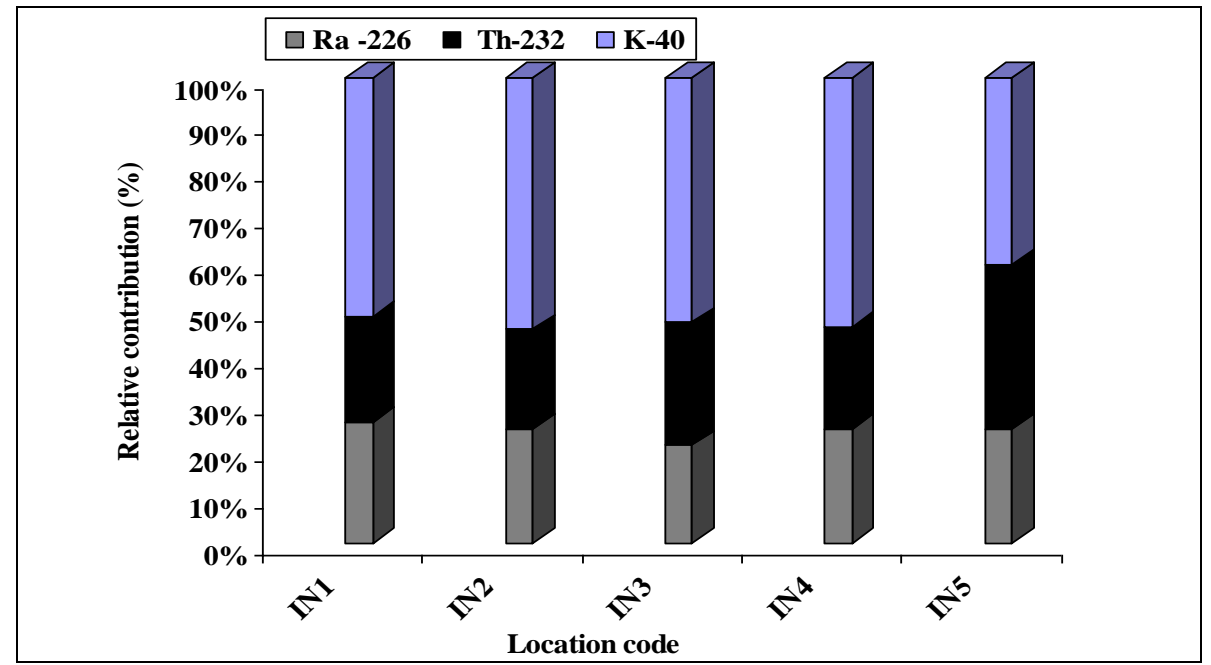

Figure 10. The Relative Contribution (\%) of ${ }^{226} \mathrm{Ra},{ }^{232} \mathrm{Th}$ and ${ }^{40} \mathrm{~K}$ to (D) and (AED) in Soil Samples from (IN)

\section{Conclusions}

As shown from the results, all the investigated islands are safe for tourists and farmers or other human activities as well as its soil can be used as a raw building material without any radiological risk. This study can be used as a baseline for future investigations and the data obtained in this study may be useful for natural radioactivity mapping.

\section{Acknowledgments}

This work was carried out using the nuclear analytical facilities at physics department, faculty of sciences, AL-Azhar University, Assiut, Egypt.

\section{References}

[1] M. M. Nermin Farag and M. H. Ayman El-Alfy, "The Role of Nile Islands in Tourist Attraction Development", World Applied Sciences Journal, vol. 21, no. 4, (2013), pp. 578-592.

[2] R. Ali Salim Zalalu, "Land Resources and Land Use Mapping of River Nile Islands", Cairo, Egypt, (In Arabic), (1989). 
[3] Y. Raslan and R. Salama, "Development of Nile River islands between Old Aswan Dam and new Esna barrages", Water, vol. 29, no. 1, (2015), pp. 77-92.

[4] Q. M. R.Nizam, M. A. Ginnah, M. M. Rahman, M. Kamal and M. I. Chowdhury, "Assessment of Activity Concentrations of Radionuclides from Upper Level Sediment in Charfassion Island, Bhola, Bangladesh", Journal of Nuclear and Particle Physics, vol. 3, no. 3, (2013), pp. 36-39.

[5] O. S. Ajayi, "Measurement of activity concentrations of ${ }^{40} \mathrm{~K},{ }^{226} \mathrm{Ra}$ and ${ }^{232} \mathrm{Th}$ for assessment of radiation hazards from soils of the southwestern region of Nigeria", Radiation Environmental Biophysics, vol. 48, no. 30, (2009), pp. 323-332.

[6] S. Issa, M. Uosif and R. Elsaman, "Gamma radioactivity measurements in Nile River Sediment samples", Turkish J Eng Env Sci., vol. 37, (2013), pp. 109-122.

[7] A. M. Shams Issa, A. M. A. Mostafa and A. El-Salam M. Lotfy, "Radiological impacts of natural radioactivity in phosphate rocks from El-Sibaiya and Red Sea coast mines, Egypt", Journal of Radioanal Nucl Chem, vol. 303, (2015), pp. 53-61.

[8] M. A. M. Uosif, A. M. A. Mostafa, R. Elsaman and E.-s. Moustafa, "Natural radioactivity levels and radiological hazards indices of chemical fertilizers commonly used in Upper Egypt", Journal of Radiation Research and Applied Sciences, vol. 7, (2014), pp. 430-437.

[9] GENIE-2000, Basic spectroscopy (Standalone) V1.2A Copyright (c), Canberra Industries (1997).

[10] I. Beretka and P. I. Mathew, "Natural radioactivity of Australian building materials, waste and byproducts", Health Physics, vol. 48, (1985), pp. 87-95.

[11] UNSCEAR. United Nations Scientific Committee on the Effects of Atomic Radiation. Sources, effects and risks of ionizing radiation. Report to the General Assembly with annex B. United Nations, New York, (2000).

[12] ICRP-60. International Commission on Radiological Protection Recommendations of the International Commission on Radiological Protection. Annals of the ICRP, vol. 21, (1991), pp. 1-3.

[13] P. Hayambu, M. B. Zaman, N. C. H. Lubaba, S. S. Munsanje and D. Muleya, "Natural radioactivity in Zambian building materials collected from Lusaka", Journal Radioanal. Nucl. Chem, vol. 199, no. 3, (1995), pp. 229-238.

[14] V. Ramasamy, G. Suresh, V. Meenakshisundaram and V. Ponnusamy, "Horizontal and Vertical Characterization of Radionuclides and Minerals in River Sediments", Applied Radiation and Isotopes, vol. 69, (2011), pp. 184-195.

[15] NEA-OECD. Nuclear Energy Agency. Exposure to radiation from natural radioactivity in building materials. Report by NEA Group of Experts. OECD, Paris, (1979).

[16] UNSCEAR United Nations Scientific Committee on Effects of Atomic Radiation. Sources and Effects of Ionizing Radiation", UNSCEAR Report, New York, (1993).

[17] N. Khalifa Ahmed and A. Gabar Mohamed El-Arabi, "Natural radioactivity in farm soil and phosphate fertilizer and its environmental implications in Qena governorate, Upper Egypt", Journal of Environmental Radioactivity, vol. 84, (2005), pp. 51-64.

[18] B. Kucukomeroglu, A. Kurnaz, R. Keser, F. Korkmaz, N. T. Okumusoglu, G. Karahan, C. Sen and U. Cevik, "Radioactivity in sediments and gross alpha-beta activities in surface water of Firtına River, Turkey”, Environ Geol, vol. 55, (2008), pp. 1483-1491.

[19] S. Harb, A. I. Abd El-Mageed, A. H. El-Kamel, A. Abbady and W. Rashed, "Radioactivity levels and Soil-to-Plant transfer factor of natural radionuclides from Protectorate area in Aswan, Egypt", World Journal of Nuclear Science and Technology, vol. 4, (2014), pp. 7-15.

[20] H. M. Diab, S. A. Nouh, A. Hamdy and S. A. EL-Fiki, "Evaluation of Natural Radioactivity in a cultivated Area around a Fertilizer Factory", Journal of Nuclear and Radiation Physics, vol. 3, no. 1, (2008), pp. 53-62.

[21] I. H. SALEH, "Radiological Study on Soils, Foodstuff and Fertilizers in the Alexandria Region, Egypt", Turkish J. Eng. Env. Sci., vol. 3, (2007), pp. 19-17.

[22] N. Akhtar, M. Tufail, M. Ashraf and M. Mohsin Iqbal, "Measurement of environmental radioactivity for estimation of radiation exposure from saline soil of Lahore, Pakistan", Radiation Measurements, vol. 39, (2005), pp. 11-14.

[23] European Commission, Radiological Protection Principles Concerning the Natural Radioactivity of Building Materials (Radiation Protection 112). Office for Official Publications of the EC, (2000). 